\title{
KAJIAN LITERATUR TENTANG PENTINGNYA SIKAP ILMIAH
}

\author{
Hunaepi \\ Dosen Prodi Pendidikan Biologi FPMIPA IKIP Mataram \\ Email: hunaepibio@ymail.com
}

\begin{abstract}
Abstrak: Berbicara tentang axiology ilmu tentu tidak bisa disangkal bahwa ilmu pengetahuan telah banyak mengubah tatanan kehidupan manusia. Kesadaran akan dampak baik dan buruk perkembangan ilmu pengetahuan sangat penting bagi kebaikan manusia itu sendiri dan di sinilah sikap ilmiah sangat diperllukan. Sikap ilmiah tidak hanya berarti sifat dasar manusia yang memiliki rasa ingin tahu namun juga menekankan pada nilai kepedulian dan menghormati nilai dari ilmu pengetahuan yang ada. Pendidikan memegang peran penting dalam menanam sikap ilmiah kepada siswa sejak dini, untuk menumbuhkan pribadi siswa yang tidak hanya cerdas intelektual, namun juga matang secara emosional.
\end{abstract}

Kata kunci: sikap ilmiah

\section{PENDAHULUAN}

Aspek penting dalam pengetahuan dan penerapannya adalah aspek afektif atau sikap atau dalam pembelajaran sains sering dikenal dengan istilah sikap ilmiah. Dalam aspek sikap ilmiah, siswa dibelajarkan untuk membandingkan fakta yang ditemui terhadap dampak yang mungkin terjadi terhadap hasil belajar. Aspek sikap ilmiah lebih berorientasi pada rasa atau kesadaran. Banyak dikalangan para ahli menginterpretasikan ranah afektif menjadi sikap, nilai sikap yang diartikan tentu akan berpengaruh terhadap penyusunan tujuan instruksional yang akan ditetapkan dalam tujuan pembelajaran. Beberapa pertanyaan penting yang akan dijabarkan dalam artikel ini diantaranya:

1. Bagaimana pentinnya sikap ilmiah?

2. Sudahkah sikap ilmiah terintegrasi dalam model pembelajaran yang diterapkan oleh guru di sekolah? Jika sikap ilmiah sudah teeintergasi, sudah terlihatkah sikap ilmiah tersebut? Bagaimana memunculkan sikap ilmiah?

Pertanyaan-pertanyaan tersebut akan diuraikan berdasarkan kajian teori maupun emperis yang telah dilakukan penulis.

\section{PEMBAHASAN}

Bagaimana pentinnya sikap ilmiah?

Pophan (1995) dalam Andeson dan Krathwohl (2001), mengatakan bahwa ranah sikap ilmiah menentukan keberhasilan seseorang. Artinya ranah sikap ilmiah sangat menentukan keberhasilan seorang peserta didik untuk mencapai ketuntasan dalam proses pembelajaran.

Karakteristik ranah sikap ilmiah yang terpenting diantaranya sikap, minat, konsep diri, nilai dan moral.

a. Sikap menurut Fishbein dan Ajzen (1975), yaitu suatu predisposisi yang dipelajari untuk merespon secara posistif atau negative terhadap suatu obyek, situasi, konsep dan orang. Sikap di sini adalah sikap peserta didik terhadap sekolah dan terhadap mata pembelajaran. Menurut Pophan (1999), ranah sikap peserta didik penting untuk ditingkatkan. Sikap peserta didik terhadap mata pembelajaran matematika harus lebih positif dibanding sebelum mengikuti pelajaran. Perubahan ini merupakan salah satu indicator keberhasilan guru dalam melaksanakan proses pembelajaran. Oleh karena itu, seorang guru harus membuat rencana pembelajaran termasuk pengalaman belajar yang membuat sikap peserta didik terhadap mata pembelajaran menjadi lebih posistif.

b. Menurut Getzel (1966), minat adalah suatu disposisi yang terorganisasikan melalui pengalaman yang mendorong seseorang untuk memperoleh obyek khusus, aktivitas, pemahaman dan keterampilan untuk tujuan perhatian atau pencapaian. Hal yang penting dalam minat adalah intensitasnya. Secara umum minat termasuk karakteristik afektif yang memiliki intensitas tinggi. Jika seseorang berminat terhadap sesuatu maka orang tersebut akan melakukan langkah - langkah konrit untuk mencapai hal tersebut.

c. Konsep diri adalah evaluasi yang dilakukan individu bersangkutan terhadap kemampuan dan kelemahan yang dimilikinya. Arah konsep diri bisa posistif bisa juga negative. Intensitasnya bisa dinyatakan dalam suatu daerah kontinu yaitu mulai dari yang rendah sampai yang tinggi.

d. Nilai menurut Tayler (1973), adalah suatu obyek, aktivitas atau ide yang dinyatakan oleh individu dalam mengarahkan minat, sikap dan kepuasan. Nilai berakar lebih dalam dan lebih stabil dibandingkan dengan sikap individu. Bahkan beberapa ahli mengatakan bahwa nilai merupakan kunci bagi lahirnya sikap dan perilaku seseorang. Manusia mulai belajar menilai obyek, aktifitas, dan ide sehingga obyek ini pengatur penting minat, sikap dan kepuasa. Sekolah (guru) harus membantu peserta didik untuk menemukan dan menguatkan nilai yang bermakna dan signifikan bagi peserta didik dalam memperoleh kebahagiaan personal dan member kontribusi positif terhadap masyarakat.

e. Moral secara bahasa berasal dari bahasa latin mores yang artinya tata cara, adat kebiasaan social yang dianggap permanen sifatnya bagi ketertiban dan kesejahteraan masyarakat. Moral menyinggung akhlak, tingkah laku, karakter seseorang atau kelompok yang berperilaku pantas, baik dan sesuai dengan hukum yang berlaku. Proses belajar akhlak (moral) memegang peranan penting, begitu juga perkembangan kognitif memberikan pengaruh besar terhadap sifat perkembangan tingkah laku (moral).

Sikap imiah merupakan disposisi berpikir yang menjadi tren penelitian yang terintegrasi dalam keterampilan berpikir tingkat tinggi seperti berpikir kritis, kreatif, metakognisi, problem solving dan decision making serta sangat menentukan kualitas individu siswa. Facione (2011) menyatakan bahwa sikap ilmiah seperti: 1) keingintahuan; 2) kepedulian; 3) kewaspadaan; 4) kepercayaan; 5) kepercayaan- diri; 6) berpikir terbuka; 7) fleksibilitas; 8) menghormati pendapat-pendapat orang lain; 9) berpikir adil; '10) jujur; 11) kehati-hatian; 12) kesediaan untuk mempertimbangkan kembali dan merevisi pandangan di mana refleksi yang jujur menunjukkan diperlukannya perubahan; menjadi disposisidisposisi berpikir yang mencirikan kualitas berpikir seseorang. 
Sudahkah sikap ilmiah terintegrasi dalam model pembelajaran yang diterapkan oleh guru di sekolah? Jika sikap ilmiah sudah teeintergasi, sudah terlihatkah sikap ilmiah tersebut? Bagaimana memunculkan sikap ilmiah?

Berdasarkan kajian teoritis maupun empiris, penulis dapat menyimpulkan bahwa setiap model pembelajaran yang ada dan sering digunakan guru dalam proses pembelajaran sejatinya telah mengintegrasikan karakteristik-karakteristik sikap ilmiah, namun siswa sering tidak menyadari ha tersebut hingga tidak tertanam dengan baik dalam benak siswa. Dewey dan Friere dalam Gautreau dan Binns (2012) menyatakan bahwa kurikulum berbasis inkuiri dimulai dengan asumsi bahwa siswa membangun pengetahuan dan makna melalui pengalaman mereka sedangkan pembelajaran tradisional beroperasi dengan kepercayaan bahwa pengetahuan berasal dari luar diri siswa, objektif, dan dapat ditrasfer oleh guru pada siswa. Pendapat tersebut mengindikasikan bahwa pembelajaran seharusnya dilakukan dengan proses-proses interaktif yang objektif serta sesuai dengan konteks kehidupan nyata siswa atau lebih sering dikenal dengan istilah kearifan lokal daerah setempat.

Uraian tersebut di atas itulah yang kurang diperhatikan guru dalam proses pembelajaran sehingga meskipun pada dasarnya model pembelajaran telah mengintegrasikan dan menekankan sikap ilmiah dalam pembelajaran. Disamping itu, kendala yang sering ditemukan guru sehingga kurang memperhatikan aspek sikap ilmiah adalah kurannya instrumen yang valid baik untuk mengukur maupun mengobservasi sikap ilmiah siswa (Facione dalam Nur, 2013).

Ranah afektif tidak dapat diukur seperti halnya ranah kognitif, karena dalam ranah afektif kemampuan yang diukur adalah: Menerima (memperhatikan), Merespon, Menghargai, Mengorganisasi, dan Karakteristik suatu nilai. Skala yang digunakan untuk mengukur ranah afektif seseorang terhadap kegiatan suatu objek diantaranya skala sikap. Hasilnya berupa kategori sikap, yakni mendukung (positif), menolak (negatif), dan netral. Sikap pada hakikatnya adalah kecenderungan berperilaku pada seseorang. Ada tiga komponen sikap, yakni kognisi, afeksi, dan konasi. Kognisi berkenaan dengan pengetahuan seseorang tentang objek yang dihadapinya. Afeksi berkenaan dengan perasaan dalam menanggapi objek tersebut, sedangkan konasi berkenaan dengan kecenderungan berbuat terhadap objek tersebut. Oleh sebab itu, sikap selalu bermakna bila dihadapkan kepada objek tertentu.

Skala sikap dinyatakan dalam bentuk pernyataan untuk dinilai oleh responden, apakah pernyataan itu didukung atau ditolaknya, melalui rentangan nilai tertentu. Oleh sebab itu, pernyataan yang diajukan dibagi ke dalam dua kategori, yakni pernyataan positif dan pernyataan negatif. Salah satu skala sikap yang sering digunakan adalah skala Likert. Dalam skala Likert, pernyataan-pernyataan yang diajukan, baik pernyataan positif maupun negatif, dinilai oleh subjek dengan sangat setuju, setuju, tidak punya pendapat, tidak setuju, sangat tidak setuju.

Sikap ilmiah siswa dapat dimunculkan melalui kegiatankegiatan interaktif berbasis kearifan lokal sehingga dapat memupuk fleksibelitas, kurositas dan minat belajar siswa seperti yang direkomendasikan Dewey dan Fiere. Guru dapat berinovasi dengan mengembangkan baha ajar yang sesuai seperti buku ajar siswa (BAM), lembar kegiatan siswa (LKS) dan lembar observasi yang mengintegrasi indicator-indikator sikap ilmiah.

LKS dan BAM merupakan suatu bahan ajar memuat mater pelajaran yang dikemas sedemikian rupa, sehingga siswa dapat belajar secara mandiri (Damayanti, Ngazizah, dan Setyadi, 2013).
Rohaeti, Widjajanti, dan Padmaningrum (2007), menyatakan bahwa keberadaan LKS sebagai suatu media pembelajaran cetak (hand out) berperan untuk membantu siswa belajar secara terarah. Untuk mendukung siswa dapat belajar secara terarah, mandiri, melatih keterampilan-keterampilan proses untuk melatihkan kemampuan berpikir siswa (Damayanti; Ngazizah; dan Setyadi, 2013; Rohaeti, Widjajanti, dan Padmaningrum, 2007). Untuk menarik rasa ingin tahu siswa guru dapat menggunakan fenomena-fenomena kontekstual kearifan lokal sehingga pembelajaran menjadi bermakna serta dapat memunculkan sikap ilmiah siswa. Ibarahim (2008) menyatakan bahwa pembelajaran yang bermakna dan menekankan pada sikap ilmiah siswa dapat dilakuakan dengan pemberian contoh fenomena sekitar dan meminta atau menyajikan makna hal tersebut kepada siswa.

Penilaian merupakan salah satu teknik yang digunakan untuk mengetahui tingkat pencapaian siswa. Penilaian dapat dilkaukan, jika tersedia instrumen/alat penilaian, baik menggunakan instrumen berupa tes, maupun berupa lembar pengamatan. Penilaian dapat dilakukan menggunakan instrumen tertulis, atau teknik penilaian menggunakan strategi tertulis dengan bentuk soal uraian untuk mengetahui sikap ilmiah siswa dengan memperhatikan indicator-indikator sikap ilmiah.

\section{KESIMPULAN}

Berdasarkan uraian yang telah disampaikan maka dapat disimpulkan bahwa sikap ilmiah sangat penting untuk dibelajarkan, manusia berpikir bukan karena manusia senang untuk berpikir, namun berpikir disebabkan manusia menghadapi masalah, kegiatan berpikir merupakan ciri dasar manusia yang menunjukkan bahwa manusia memiliki raasa ingin tahu akan masalah yang dihadapi. Model-model pembelajaran yang telah ada dan sering digunakan guru dalam proses pembelajaran di dalam kelas memang telah mengintegrasikan sikap-sikap ilmiah namun dalam pelaksanaannya sikap ilmiah ini kurang maksimal dalam pengkondisiannya sehingga sering kabur dan membuat siswa tidak sadar akan sikap ilmiah itu sendiri.

Penyediaan bahan ajar yang lebih mengutamakan kontektualisasi dan pemaknaan materi ajar sangat dibutuhkan untuk menumbuhkan sikap ilmiah siswa.

\section{DAFTAR PUSTAKA}

Adisendjaja dan Romlah, 2007. Analisis Buku Ajar Sains Berdasarkan Literasi IImiah Sebagai Dasar untuk Memilih Buku Ajar Sains (Biologi). Jurnal Pendidikan Biologi FPMIPA Universitas Pendidikan Indonesia.

Adisendjaja, 2010. Analisis Buku Ajar Biologi SMA Kelas X di Kota Bandung Berdasarkan Literasi Sains. Jurnal Pendidikan Biologi FPMIPA Universitas Pendidikan Indonesia.

Anderson, L.W., Krathwohl, D.R., and Airasian, P.W., 2001. A Taxonomy for Learning, Teaching, and Assesing, A Revision of Bloom's Taxonomy of Educational Objectives. New York: Addison Wesley Longman, Inc.

Damayanti, Ngazizah, dan Setyadi, 2013. Pengembangan Lembar Kerja Siswa (LKS) Dengan Pendekatan Inkuiri Terbimbing Untuk Mengoptimalkan Kemampuan Berpikir Kritis Peserta Didik Pada Materi Listrik Dinamis SMA Negeri 3 Purworejo Kelas X Tahun Pelajaran 2012/2013. Radiasi. Vol.3 .No.1 Progam Studi Pendidikan Fisika Universitas Muhammadiyah Purworejo. 
Facione, Peter. 2011. Critical Thinking. What It Is and Why lts Counts. Measured Reason and The California Academic Press.

Ibrahim, M., 2008. Model Pembelajaran Inovetif IPA Melalui Pemaknaan. Surabaya: Departemen Pendidikan Nasional Balitbang.
Rohaeti, Widjajanti, dan Padmaningrum, 2007. Pengembangan Lembar Kerja Siswa (LKS) Mata Pelajaran Sains Kimia Untuk Smp Kelas VII, VIII, dan IX. Artikel Penelitian Dosen Jurusan Pendidikan Kimia FPMIPA UNY. 